[Forthcoming in Journal of the History of Philosophy]

\title{
Schopenhauer and Non-Cognitivist Moral Realism
}

\author{
Colin Marshall
}

\begin{abstract}
I argue that Schopenhauer's views challenge the widely-held belief that moral realism requires cognitivism about moral judgments. Schopenhauer's core metaethical view consists of two claims: that moral worth is attributed to actions based in compassion and that compassion, in contrast to egoism, arises from deep metaphysical insight into the non-distinctness of beings. These claims, I argue, are sufficient for moral realism, but are compatible with either cognitivism or non-cognitivism. While Schopenhauer's views of moral judgment are not obviously consistent, I show how various passages suggest a form of non-cognitivism. This non-cognitivism, I claim, is compatible with moral realism.
\end{abstract}

Schopenhauer has been ignored in contemporary metaethics, and Schopenhauer's commentators rarely attempt to analyze his metaethical views in contemporary terms. This is unfortunate. Schopenhauer has something important to teach us about moral realism. ${ }^{1}$

I have both philosophical and interpretive aims in this paper. My philosophical aim is to show how Schopenhauer's views challenge the contemporary understanding of moral realism. The challenge arises from the fact that while Schopenhauer's view implies that morality is "real" in a metaphysically- and epistemologically-robust sense, that view denies (or at least, is compatible with denying) a central piece of the contemporary definition of moral realism: the

1 For references to Schopenhauer's work in what follows, I will use the following abbreviations: The World As Will and Representations (WWR), On the Freedom of the Will (OFW), On the Basis of Morals (OBM), On Will in Nature $(O W N)$. Page numbers will be to the English translation listed in the Works Cited. Since several translations of $O B M, O F W$, and the first volume of $W W R$ are widely used, for these works I also provide the relevant volume and page numbers from the collected works edited by Arthur Hübscher, indicated with an 'H.' 
cognitive (i.e. truth-apt or belief-expressing) character of moral judgments. For while

Schopenhauer sometimes seems to deny that moral judgments are truth-apt, he nonetheless holds that they have a certain profound epistemic value. Their having this value ultimately implies that malice and egoism can arise only from an epistemic lack. If such a view is consistent, I hold, then the contemporary understanding of moral realism is too narrow. ${ }^{2}$ The broader implication of this challenge is that contemporary metaethics has focused too narrowly on moral judgments. If Schopenhauer gives us reasons to widen our metaethical perspective, then his views deserve more attention than they have received.

My interpretive aim of this paper is to show that Schopenhauer is a moral realist, and that some elements of his views suggest a novel form of non-cognitivism about moral judgments. While many previous commentators have discussed Schopenhauer's metaethics, there are as of yet no published attempts to explicitly classify his metaethical views, especially with respect to moral realism vs. anti-realism. ${ }^{3}$

In $\S 1$, I describe the contemporary consensus among metaethicists that cognitivism about moral judgments is a necessary condition for moral realism. In $§ 2, \mathrm{I}$ describe Schopenhauer's core metaethical view, which he dubs his "metaphysical grounding" for morals. That core view has no direct implications concerning cognitivism, so $\S 3$ considers Schopenhauer’s complex

2 The contemporary understanding is more frequently challenged for being too wide, since it seems that certain "quasi-realist" views are able to satisfy it without deviating from a fundamentally anti-realist orientation. For one important discussion, see Drier, "Meta-Ethics and the Problem of Creeping Minimalism." Note that my use of "judgment" is meant to be neutral about cognitivism, so judgments should be understood as the uncontroversial elements of moral discourse.

3 In a relatively recent collection of essays on Schopenhauer's philosophy of value (Neill and Janaway, Better Consciousness), for example, none of the authors directly addresses the question of whether Schopenhauer is a moral realist or antirealist. In his introduction to the volume, Christopher Janaway states that "we ultimately find nothing but an absence of value" (Janaway, "Schopenhauer's Philosophy of Value," 1-2) in Schopenhauer's philosophy, which suggests that he takes Schopenhauer to be an anti-realist, though Janaway then goes on to say that Schopenhauer finds "a higher value" in some states (Janaway, "Schopenhauer's Philosophy of Value," 2). This question is also not directly addressed in any of the essays in Vandenabelle, A Companion to Schopenhauer. In unpublished work (Shapshay, "Schopenhauer on the Moral Considerability of Animals"), Sandra Shapshay offers a realist reading of Schopenhauer that resembles certain realist readings of Kant. Shapshay's reading differs from mine on several points, but I will not attempt a comparison here. 
views of moral judgment. As we will see, while some of Schopenhauer's claims do suggest cognitivism, there are significant grounds for taking him to be an unusual sort of non-cognitivist. $\S 4$ spells out why that non-cognitivism would both (a) be consistent with Schopenhauer's core view and (b) not threaten its claim to realism.

Two caveats. First: I will not be arguing that Schopenhauer's views are correct. His metaethics appeals to a radical metaphysical monism that few contemporary philosophers would take seriously. ${ }^{4}$ That metaphysics, however, is not obviously more radical than Plato's, and metaethicists do take Plato's views seriously (at least for the sake of understanding the range of possible views). The question of whether there is a metaphysically plausible form of moral realism along Schopenhauerian lines will have to wait for another occasion, though I will note some possible lines of development in $\S 4$.

Second: My discussion concerns what I take to be the core of Schopenhauer's metaethics, but sets aside four related views he holds (concerning freedom, universal justice, satisfaction in virtue, and the denial of the will). ${ }^{5}$ Considering these views would be essential for a full

4 As an indication of its radical nature: Schopenhauer also thinks this metaphysical view explains the possibility of magic (see his $O W N$ 416-17). For some concerns about the views I describe below, see Magee, The Philosophy of Schopenhauer, 243, Atwell, Schopenhauer: The Human Character, Part II, Cartwright, "Compassion and Solidarity with Sufferers," 303-04, and Guyer, "Schopenhauer, Kant, and Compassion."

5 More specifically, Schopenhauer holds: (i) That our will is free, in a morally-significant sense. Schopenhauer says, "[m]y philosophy... is the only one that grants to morality its complete and entire rights; for only if the true nature of man is his own will... are his deeds actually entirely his and attributable to him" (WWR II 589). See also H 4:72/OFW 96 and the final chapter of On the Will in Nature. Like Kant, Schopenhauer makes such claims while endorsing a form of determinism (see H 4:95-98/ OFW 114-16). (ii) That there is universal justice (ewige Gerechtigkeit, see H 2:414/WWR I 377), since "tormenter and the tormented are one" (H 2:419/WWR I 381). It is not obvious how this is consistent with Schopenhauer's claims in $O B M$ that people can have the virtue of justice in greater or lesser degrees. (iii) That compassionate action leads to a sort of satisfaction (see H 2:441/WWR I 400, H4. 272/OBM 269). Given Schopenhauer's opposition to eudaimonism (see H 4:117/OBM 134), it is plausible that such rewards of virtue are not essential to his grounding of morality. (iv) That morality is a step towards salvation or the denial of the will. Schopenhauer states that the moral virtues "are not really the ultimate end, but only a step towards it... [W] hat is moral... accompanies man as a light on his path from the affirmation to the denial of the will" ( $W W R$ II, 608). This is connected to Schopenhauer's pessimism about the world: "we have not to be pleased but rather sorry about the existence of the world... [I]ts nonexistence would be preferable to its existence" (WWR II 576). All of these views have some bearing on the question of how to categorize Schopenhauer's metaethics. Views i and iii may align Schopenhauer with some traditional forms of moral realism. View ii seems neutral on the question of realism, and View iv may suggest anti-realism. These suggestions, however, are less clear than the views that Schopenhauer himself identifies as forming the basis of morality. 
understanding of Schopenhauer's overall ethics, but is not essential for the present topic. To keep the discussion manageable, I also set aside issues concerning Schopenhauer's aesthetics, though I believe that a parallel argument can be made for regarding Schopenhauer as a non-cognitivist aesthetic realist.

\section{The History of Moral Realism and Cognitivism}

Why should we care about how $20^{\text {th }}$ century piece of jargon like 'moral realism' applies to pre- $20^{\text {th }}$ century philosophers? The phrase 'moral realism,' one might think, has a stipulative definition, and contemporary philosophers can stipulatively define their jargon however they like. If that stipulative definition includes cognitivism, then no appeal to the history of philosophy could show that moral realism is compatible with non-cognitivism.

As it turns out, 'moral realism' is not merely stipulatively defined in contemporary metaethics. Rather, many contemporary philosophers intend that the term refer to a family of views that goes back at least to Plato. These views are united by their attempt to show, against moral skeptics and moral nihilists, how morality can be "real" in some important way. In perhaps the most influential discussion of metaethical taxonomies, Geoffrey Sayre-McCord writes that,

The realism/anti-realism debate in ethics has been around ever since people began thinking critically about their moral convictions. The problem has always been to make sense of these convictions in a way that does justice to morality's apparent importance without engaging in outrageous metaphysical flights of fancy. Some have thought it can't be done; they've held that the apparent importance of morality is mere appearance. Others have thought it can be done; they've held that whatever metaphysics is necessary is neither outrageous nor fanciful. ${ }^{6}$

6 Sayre-McCord, "Introduction," 2. 
Similarly, in his landmark 1986 paper, "Moral Realism," Peter Railton introduces his topic in terms of attempts to resist moral skepticism and "establish the objectivity of morality." Railton notes, though, that "[t]he history of such attempts hardly inspires confidence." ${ }^{7}$ More recently, Sharon Street has claimed that the "whole point" of genuine moral realism is that it "vindicates morality if correct," such that obviously immoral agents are "making a mistake ... [or] missing something." Street worries that some recent forms of "moral realism" fail to do this, even though they satisfy some other definitions for moral realism. ${ }^{8}$ Talk of moral realism, then, is intended to capture the long history of attempts to do justice to the apparent importance of morality, find alternatives to skepticism, show that morality is objective, and prove that all obviously immoral agents are missing something.

Given this ambition, it is not surprising that it is difficult to find a precise but extensionally-adequate definition of 'moral realism.' The most-discussed issues in this regard are (a) whether a moral realist must take morality to be mind-independent in some sense ${ }^{9}$ and (b) whether any characterization of moral realism is immune to appropriation by sophisticated forms of anti-realism. ${ }^{10}$ One point of consensus among contemporary metaethicists, however, is that a necessary condition for moral realism is that some moral sentences or judgments (that is, sentences or judgments containing distinctively moral terms or concepts) be both truth-apt and true. Sayre-McCord, for example, concludes that "moral realism is defensible if, but only if, there is some plausible account of the truth-conditions of moral claims that captures their literal

7 Railton, "Moral Realism," 163. Railton notes that a wide range of views have been claimed the title of moral realism, and makes clear that his use of the term is not "proprietary" (Railton, "Moral Realism," 164-65).

8 Street, "Reply to Copp," 223.

9 For one helpful discussion, see Joyce, "Moral Anti-Realism."

10 Blackburn, Essays in Quasi-Realism, Gibbard. Thinking How to Live, Drier. "Meta-Ethics and the Problem of Creeping Minimalism." 
meaning and that makes sense of some of them being literally true."11 The view that moral sentences or judgments are truth-apt is typically called 'cognitivism. ${ }^{12}$ Nowhere I know of is the possibility of a non-cognitivist form of realism seriously considered in the contemporary literature. $^{13}$

I now turn to arguing that Schopenhauer can show us how to make sense of such a view. If that is right, then it shows that the contemporary understanding of 'moral realism' is too narrow.

\section{Schopenhauer's core metaethical view}

11 Sayre-McCord, "Introduction," 22. Sayre-McCord was not the first to make such a connection. In his 1971 article, "Moral Realism," Simon Blackburn defined moral realism as "the view that the truth of moral utterances is to consist in their correspondence with some fact or state of affairs" (Blackburn, "Moral Realism," 111). Similarly, in her 1983 article on moral realism, Philippa Foot begins by saying that she will talk of moral realism and cognitivism interchangeably (Foot, "Moral Realism and Moral Dilemma," 379). To give two more recent but telling examples: Graham Oddie claims that the denial that statements of a given discourse express propositions (which he labels "non-cognitivism") is the lowest degree of realism, lower even than nihilism (Oddie, Value, Reality, and Desire, 22-23). Russ Shafer-Landau defines moral realism as the theory that "moral judgments ... when true, are so independently of what any human being, anywhere, in any circumstances whatever, thinks of them" (Shafer-Landau, Moral Realism, 2).

12 From a historical perspective, this is a quite narrow use of "cognitive." For instance, Kant sometimes counts the state of seeing something for which one has no concept as a type of cognition (Lectures on Logic, 544-45). The same is true for Schopenhauer (at least, insofar as we take him to follow Kant in using "Erkenntnis" for cognition; see H 4:246/OBM 246). In what follows, I stick with the contemporary narrow use of "cognitive" as restricted to sentences and judgments, and it is only in this contemporary sense that the position I describe in later sections counts as non-cognitivist.

13 David Copp has defended a view he dubs "realist-expressivism," but this is a form of cognitivism (see Copp, "Realist-Expressivism and Conventional Implicature," 168). In her earlier work, Christine Korsgaard described her view as "procedural realism" (Korsgaard, The Sources of Normativity, 34-37), while emphasizing that description was not the primary role of ethical concepts (Korsgaard, The Sources of Normativity, 46). More recently, however, she has stopped calling her view a form of moral realism, and allowed that her view is cognitivist (Korsgaard, The Constitution of Agency, 22, 302ff.). The closest thing I am aware of to an explicit proposal of non-cognitivist realism is a suggestion by Hallvard Lillehammer: "For those who still search for a fresh slice of metaethical terrain on which to stake their claim, the search continues. What about non-cognitivist moral realism? Too implausible even to contemplate? Not if you are prepared to seriously consider the unknowability of moral facts." (Lillehammer, "Review of Russ Shafer-Landau, Moral Realism"). The direction Lillehammer hints at here is not the one I will be exploring, though there may be a way of construing Schopenhauer's view in terms of unknowable moral facts. 
My aim in this section is to describe the central pieces of Schopenhauer's metaethics, or what I call his core metaethical view. This view is neutral on whether moral judgments are truthapt. Despite that, I will argue that the view is recognizably realist: it is directly opposed to the idea that morality arises from an illusion, and aims to show that morally admirable people have a profoundly better grasp of reality than obviously immoral people like egoists and sadists. ${ }^{14}$ In Sayre-McCord's terms, Schopenhauer's core view implies that the importance of morality is not "mere appearance."

Schopenhauer's main presentation of his metaethical views is found in the third and fourth parts of his essay, On the Basis of Morals (OBM), though much of what he says there echoes claims made earlier in the fourth book of his central work, The World as Will and Representation $(W W R)$. My focus in what follows will be on $O B M$, which Schopenhauer points to as his main explanation (see $W W R$ II, 601), though I will draw on $W W R$ at various points. Since $O B M$ was originally written for a blind-reviewed competition (which, despite being the only entry, it did not win), Schopenhauer leaves out many of the more distinctive theses of WWR. These theses, however, are not essential to his core metaethical view. That core view consists of two claims, which are the focal points of the third and fourth parts of $O B M$, respectively: (I) that moral worth is generally attributed to actions motivated by compassion, except by Europeans under the sway of a certain conceptual confusion and (II) that compassion arises from a deep metaphysical insight, whereas egoism and malice arise only insofar as the agent is subject to metaphysical illusion. Before discussing those claims, however, I will consider how Schopenhauer views his own metaethical project.

14 In the Preface to his essay, Schopenhauer himself distinguishes morals from morality, where the latter is moral philosophy. This distinction will not be important for my argument. 


\subsection{Schopenhauer's approach to metaethics}

Schopenhauer takes his topic in $O B M$ to be "nothing less than the objectively true basis of morals," or, what he takes to be the same thing, the "purely philosophical, objective, unveiled, and naked exposition of the ultimate ground for all morally good conduct, i.e., independent of all positive laws, all unproven presuppositions, and as a result of all metaphysical or even mythological hypostases" (H 4.107/OBM 125).

Schopenhauer takes this to be a long-standing philosophical topic: "the philosophers of all times and lands have ground their teeth to stumps on it" (H 4.108/OBM 125), going back at least until Socrates (H 4.114/OBM 131, WWR II 590). He contrasts his attempt to find the objectively true basis of morals with the "skeptical view":

Or perhaps upon retrospection on the attempts made in vain for more than two thousand years to find a secure basis for morals, might it result that there is simply no natural morals independent of human ordinance, but this is an artifact through and through, a means discovered the better to restrain the selfish and malicious human race, and that, consequently, without the support of positive religions, this would collapse because it had no inner verification and no natural basis? (H 4.186/OBM 194)

At the same time, Schopenhauer does not aim to convert any of his readers to moral goodness: "no one can be talked out of egoism or malice any more than the cat can be of its inclination to mousing” (H 4.255/OBM 255, see also H 2.319/WWR I 297). ${ }^{15}$

The challenge of grounding morals is also distinguished from finding a unified first-order

15 See also $\mathrm{H}$ 4:52/OFW 77: "no moral influence extends further than the correction of knowledge, and to undertake to eliminate a person's character flaws through lectures and moralizing... is just like a plan to change lead into gold through external influence or to bring an oak through careful cultivation to the point that it bears apricots." 
ethical principle, though Schopenhauer claims to do that too. Unlike the difficult question of determining the grounds of morality, Schopenhauer thinks that the core principle of morality is already well known, and takes his contribution to be primarily a matter of formulation:

I will trace... that fundamental proposition [of virtue], about the content of which all moral philosophers are actually in agreement no matter how many different forms in which they dress it, back to the expression which I hold to be the purest and simplest of all: 'Harm no one; rather, help everyone as much as you can.' (H 4.137/OBM 150-51)

Schopenhauer calls this the "what" of virtue, whereas the grounding question is the "why" (H 4.136/OBM 150).

In all this, Schopenhauer sounds quite a bit like a contemporary metaethicist. He takes his topic to be one that stretches back to ancient Greece, but distinguishes it both from moral exhortation and from first-order ethics. So far, he also sounds like a moral realist, insofar as he both contrasts his view with skepticism and with the view that morality is dependent on "human ordinance," and claims to be looking for a basis for morals that is "objectively true."

There are some complexities to Schopenhauer's metaethical project, however. He draws a sharp distinction (reminiscent of one in Kant's Groundwork) between two stages of the grounding project and devotes more attention to the first. ${ }^{16}$ The first stage sounds psychological: “interpreting, expounding, explaining, and reducing to their ultimate ground humans' ways of acting" (H 4.195/OBM 201), with the particular aim of finding the moral incentive. The second stage asks for the "ultimate explanation" of compassion, which the first stage identifies as the only moral incentive (see H 4.260-61/OBM 259). Though Schopenhauer focuses more on the first stage in $O B M$, he insists that without the second, the first will be "necessarily incomplete"

16 In the Preface Schopenhauer wrote later, however, he insists that these stages are linked and equally important (H4. ix-xii/OBM 6-8). This was prompted by the details of the Danish Society's judgment on his essay (see H $4: 276 / O B M 272)$. 
(H 4.108/OBM 126). In fact, he claims that a full solution requires not just a metaphysical explanation of morality, but a complete metaphysical system, since "[a] metaphysics of nature, a metaphysics of morals, and a metaphysics of the beautiful mutually presuppose one another" (H 4.109/OBM 127). The brevity of the metaphysical discussion in the $O B M$ is partly due to Schopenhauer's attempt to avoid revealing his identity for the sake of the contest.

One striking feature of the first stage of Schopenhauer's project is his claim that his method is empirical. Here is the larger context for one of the above quotes:

I set for ethics the purpose of interpreting, expounding, explaining, and reducing to their ultimate ground humans' ways of acting, which from a moral view are extremely variable. Therefore there remains no other path to the discovery of the foundations of ethics than the empirical, specifically to investigate whether there are any actions at all to which we must grant genuine moral worth.

(H 4.195/OBM 201)

In principle, Schopenhauer allows both introspection and outer observation on this path: "given the isolation of ethics from all metaphysics made necessary by the task, nothing remains but an analytic method which proceeds from either facts of external experience or facts of consciousness. These latter can trace it back to its ultimate root in the human mind" (H 4.109110/OBM 127). In the course of his argument, however, it becomes clear that Schopenhauer privileges external experience, saying that "as with others, so we come to know ourselves only empirically" (H 4.178/OBM 186) and that "it is just as certain that there are actions of disinterested loving kindness and completely voluntary justice. I do not find proofs of these in facts of consciousness, but only in experience" (H 4.191/OBM 198) ${ }^{17}$ This method is important,

17 A helpful example of this empirical method is Schopenhauer's argument for the apriority of the concepts of right and wrong: "the fundamental concepts of wrong and right... everyone grasps a priori and immediately applies on the occasion of experience. For the dubious empiricist, since for him only experience is relevant, one may refer to savages who all quite correctly, often even precisely and exactly, distinguish wrong and right, which is quite apparent in their bartering and other transactions with the crews of European ships" (H 4:218/OBM 221). See also his appeal to "the linguistic usage of all peoples" in critiquing Kant's identification of virtue and rationality (H $4: 150 / O B M 162)$. 
Schopenhauer states, because "morals concern the real acting of human beings, and not a priori houses built of cards" (H 4.143/OBM 156).

It is not obvious how a purely empirical method could show there are actions of genuinely moral worth. This brings us to the question of how to understand Schopenhauer's first claim.

2.2. Compassion and the attribution of moral worth

Schopenhauer formulates the main claim of the first stage of his project in several different ways. At $\mathrm{H} 4.208 / O B M 213$, he formulates it as: "Only insofar as an action has originated from compassion does it have moral worth.” As such, this does not look like a conclusion that "external experience" alone could justify. In addition, some of the arguments Schopenhauer gives are hard to read as empirical arguments (e.g. the thought experiment at $\mathrm{H}$ 4.231-32/OBM 233-34). Schopenhauer gives another formulation of his main claim, however, that fits better with his methodological statements:

Actions of the sort mentioned above [e.g. helping "without having ... a further intention than that the other ... be helped" (OBM 208/H203)] are those to which genuine moral worth is attributed [denen man eigentlichen moralischen Werth zugesteht]. As the special feature and characteristic of such actions, we find the exclusion of any sort of motives by which all human actions are called forth, namely the self-interested in the broadest sense of the word. (H 4.204/OBM 209) ${ }^{18}$

An empirical approach could indeed justify the claim that genuine moral worth is attributed to a

18 Strictly speaking, this is a sub-conclusion. A further inference is required to conclude that compassion is the motivation in question. Schopenhauer makes that inference via the psychological claim that the only anti-egoistic motivation comes from compassion (see H 4:205-06/OBM 210-11). 
certain class of actions. ${ }^{19}$ Who are the people who attribute moral worth to compassionate actions? Here, Schopenhauer makes a surprisingly strong claim: "in all times and in all lands, the source of morality [i.e. compassion] has been quite well known, except for in Europe" (H 4.249/OBM 249). This suggests that the attribution of genuine moral worth to compassionate actions is a general phenomenon. Schopenhauer does not mean to exclude all Europeans. Immediately after this passage, he quotes Lessing's claim that “The compassionate person is the best person, included to all social virtues, to all sorts of magnanimity" (Lessing, Gesammelte Werke, 6:395, quoted in H 4.249/OBM 249).

Before turning to Schopenhauer's explanation of why Europeans differ from the rest of the world in their attributions of moral worth, I want to note how this claim relates to cognitivism. The relation is straightforward: even the most simple forms of non-cognitivism (such as A. J. Ayer's emotivism) are consistent with the empirical claim that moral worth is attributed by a certain group of people to a certain set of actions, provided that "attributed" describes only the surface grammar of certain statements. To see this, consider the familiar emotivist analogy of cheering for athletes. Say that we understand 'you rule!' as a non-truth-apt expression of approval. On its surface, this statement attributes ruling to someone. Cognitivists and non-cognitivists could agree about who utterers of that statement attribute ruling to (say, athletes on the utterer's favorite team), though non-cognitivists will take this to be merely matter of who the feeling of approval is directed towards ${ }^{20}$ For the same reason, a non-cognitivist could

19 Bryan Magee's gloss on Schopenhauer's discussion here is helpful: "his conclusion is that even after the most sceptical analysis we still persist in regarding actions approvingly as 'moral' in so far as they rest on motives which ... are concerned with the well-being of others" (Magee, The Philosophy of Schopenhauer, 197). See also Jacquette, The Philosophy of Schopenhauer, 226.

20 Significantly, Hume (the patron saint of contemporary non-cognitivism) frequently uses passive constructions concerning attribution when describing our use of moral language. E.g. "Every quality of the mind is denominated virtuous, which gives pleasure by the mere survey; as every quality, which produces pain, is call'd vicious"

(Treatise, Book 3, Part 3, Section 1, Paragraph 30). 
agree with the claim that people attribute moral worth to compassionate actions (e.g. that these are the actions people point at when they say "that action has moral worth"). She will, however, give a deeper analysis of such attributions that shows their difference from, say, the attribution of shapes to objects. It is because of this division between surface grammar and deeper analysis that non-cognitivists can consistently make moral statements themselves. ${ }^{21}$ Whether Schopenhauer was in fact a non-cognitivist is still an open question at this point. What is important is that he formulates the main claim of the first stage of his metaethics in a way that is consistent with noncognitivism.

Still, we should consider the reasons for Schopenhauer's statement that the source of morality is not well known in Europe. This statement might suggest that the Europeans who do not recognize the connection between compassion and moral worth are making some factual mistake, and talk of factual mistakes is typically a mark of cognitivism. Schopenhauer's view, however, is that the mistake in question is conceptual, not factual. Starting with the Old Testament, Schopenhauer claims, the "dictatorial" concepts of law and obligation were introduced into ethics (H 4.121-22/OBM 137-38), ${ }^{22}$ but "separated from the theological presuppositions from which they have proceeded, these [dictatorial] concepts actually lose all meaning" (H 4.122-23/OBM 138). Schopenhauer primarily has Kant's ethics in mind here, saying that "Kant had silently and surreptitiously borrowed the imperative form of ethics from

\footnotetext{
21 For instance, Hume says, on a point very similar to Schopenhauer, that " its liberty, instead of engaging us to honest actions, is the source of all injustice and violence; nor can a man ever correct those vices, without correcting and restraining the natural movements of that appetite" (Treatise, 3.2.1.10). Given his claims to empiricism and general admiration of Hume (see Cartwright, Schopenhauer, 149, 177), it is somewhat surprising that Schopenhauer does not comment on Hume's moral philosophy in $O B M$ (his only mention of Hume in $O B M$ concerns freedom (H 4:174/OBM 184)), though he does criticize Adam Smith's view of sympathy and morality (H 4:232/OBM 233).
}

22 Schopenhauer's discussion here is tinged with anti-Semitism, which becomes even clearer later in $O B M$ (e.g. H 4:249/OBM 249). Schopenhauer's anti-Semitism leads him to overlook the significant role of compassion (rachamim) in the Jewish tradition (see, e.g. Exodus 34:6, Isaiah 49:15, and the texts quoted in Sears, Compassion in the Jewish Tradition), which could have supported his larger argument. 
theological morals ... and in fact his ethics only has meaning and sense if it is not separated from theology" (H 4.125/OBM 140). He regards Kant as the dominant thinker in European ethics: "Kant's foundation of morals even today is universally accepted and is taught everywhere" (H 4.115/OBM 132).

I will return to Schopenhauer's criticisms of Kant in $\S 3$. For now, the important point is that Schopenhauer's main criticism of non-theological European ethics is that it appeals to meaningless concepts (Schopenhauer gives no sign of taking traditional theological ethics seriously, no doubt partly because of his long-standing atheism ${ }^{23}$ ). An attribution of moral worth that was tied to such concepts may be what Schopenhauer would count as non-genuine. This is a different sort of objection than saying that Kant made a factual mistake, and it carries no direct cognitivist implications.

We have reached the first piece of Schopenhauer's core metaethical view then: moral worth is generally attributed to actions motivated by compassion, except by certain Europeans who are under the sway of a certain conceptual confusion.

\subsection{Compassion as metaphysical insight}

In the second stage of his project, Schopenhauer turns to the metaphysical basis of compassion. Though he drops his empirical methodology here ("we must now leave the firm ground of experience" (H 4.264/OBM 262)), he does emphasize that the metaphysics he appeals to "has been present for all time" (H 4.268/OBM 265), going back to the Upanishads of ancient India.

23 See Cartwright, Schopenhauer, 78-79. 
As we saw above, Schopenhauer claims that the grounding of morality would be incomplete without the metaphysical stage. In the course of his discussion, he provides two more specific reasons for turning to metaphysics. The first concerns the nature of compassion itself:

for the moment the barrier between I and Not-I has been suspended ... I suffer in him even though his skin does not enclose my nerves. Only through this can his woe, his distress, become a motive for me ... This process is ... mysterious: for it is something for which reason can give no immediate account, the grounds of which are not to be ascertained by way of experience. And yet it is an everyday occurrence. (H 4.229/OBM 231)

Schopenhauer denies that compassion can be explained in terms of imagining ourselves being in the place of the sufferer, on what appear to be phenomenological grounds: "we feel his pain as his and do not imagine that it is ours ... The explanation for the possibility of this... is not so simple that it can be attained in a merely psychological way ... It can only be deduced metaphysically" (H 4.211-12/OBM 215). Nor does Schopenhauer think that compassion arises through some abstract intellectual process: "compassion, which has proved to be the sole source of disinterested actions and consequently the true basis of morality, requires no abstract cognition, but only intuitive cognition, the mere apprehension of the concrete instance, which speaks to compassion immediately, without further mediation of thought" $\left(\mathrm{H} \mathrm{4.246/OBM} \mathrm{246)}{ }^{24}\right.$ Schopenhauer thinks that, in compassion, we immediately apprehend others' pains in a way that conflicts with our normal views about the distinctness of individuals. This appears to be why Schopenhauer thinks that compassion motivates us to help others: we literally feel, and so are moved by, their pains. This calls for a metaphysical explanation.

Schopenhauer's second reason for turning to metaphysics is more clearly metaethical

24 The immediacy in question is metaphysical, not temporal, since Schopenhauer thinks that temporality belongs to the phenomenal world that compassionate insight breaks through. So (contra Cartwright, "Schopenhauer on the Value of Compassion," 260-61) Schopenhauer's explanation allows for compassion with future beings (and, for similar reasons, merely possible beings). See H 4:267/OBM 265, H 2:447/WWR I 405. 
than the first. After saying more about how compassion, as the genuine moral incentive, involves a breakdown of the distinctness between individuals, Schopenhauer states:

Now the question arises whether the latter apprehension of the relation between one's own and another's I, which lies at the basis of actions of good character, is erroneous and rests on a deception? or whether, instead, this is the case with the opposing apprehension on which egoism and malice stand? (H 4.266/OBM 264)

In other words, Schopenhauer turns to metaphysics in part to answer the question of whether the compassionate person, in her immediate apprehension of others' pains, is in the grips of some error or deception. The presumed error would be failing to appreciate the apparent "broad chasm" or "vast distinction, between the I, which is limited to its own person, and the Not-I" (H 4.266/OBM 263).

In turning to metaphysical monism, then, Schopenhauer takes himself to find an explanation for how compassion itself works that shows that it is the egoist, not the compassionate person, who is in error:

plurality and separateness belong only to appearance, and... one and the same essence... presents itself in everything living ... [From this follows] that apprehension which suspects the distinction between I and not-I ... It is [this] view that we have found lying at the basis of the phenomenon of compassion, indeed, have found that compassion to be the real expression of this view. This view, then, would be the metaphysical foundation of ethics, and would consist in the fact that one individual immediately recognizes [unmittelbar... wiedererkenne] in another himself, his own, true essence ... [T] he one who is morally noble, even if he is so very lacking in intellectual excellence, reveals through his action the deepest knowledge [Erkenntnis], the highest wisdom [Weisheit]. (H 4.270/OBM 267) $)^{25}$

25 David Cartwright thinks that there are two quite different views here, and that in the last part of this quote Schopenhauer "distances himself from the claim that these agents are moved by a cognition that others are themselves. Instead, their behavior shows what his metaphysics explained" (Cartwright, "Compassion and Solidarity with Sufferers," 301). I am unsure why Cartwright takes Schopenhauer's talk of what is "revealed through action" to suggest that the agents are not moved by a cognition (or even, that their motivational state is itself a cognition) of the non-distinctness of themselves and others. Schopenhauer's claim is that what is revealed by action is the agent's own knowledge, not just some metaphysical truth that, as it turns out, is known to some philosophers. 
The compassionate person, on Schopenhauer's view, has a deep metaphysical insight that the egoist lacks. This insight, which Schopenhauer describes in cognitive terms (though see below), does not explicitly concern moral facts, however. ${ }^{26}$ It is an insight into the numerical sameness of essence in different individuals that coincides with, or perhaps is constituted by, feeling others' pains immediately. Schopenhauer claims that this insight is part of compassion itself, and so the basis of compassionate action. This sameness is a deep metaphysical fact, not a human artifice. Here, then, we find the second claim that defines Schopenhauer's core metaethical view: compassionate actions arises from a deep metaphysical insight, whereas egoistic and malicious actions arise only insofar as the agent is subject to metaphysical illusion. ${ }^{27}$

I will discuss the nature of this insight more in the next section. For now, though, I want to note that this claim is also neutral on the issue of cognitivism concerning moral judgments. The error of the egoist that Schopenhauer focuses on is not an error concerning which actions are right or which things are valuable. Instead, it is an error concerning whether others are metaphysically distinct from us. A moral non-cognitivist could, in principle, accept Schopenhauer's claim about the epistemological superiority of compassion over egoism.

Despite that, it should be clear that Schopenhauer's core metaethical view plausibly satisfies the informal, historical descriptions of moral realism from $\S 2$. The conjunction of the two claims I have described (that moral worth is attributed to compassionate actions and that

26 It would be consistent with Schopenhauer's core view to deny that there are any moral facts, for the same reasons that that view is consistent with non-cognitivism. However, it would also be possible to take the deep metaphysical identity of different individuals to be a moral fact or the basis for a moral fact. For example, the moral fact that someone is virtuous might be identified or grounded in the (descriptive) fact that she has deep insight into the identity of individuals. This might be analogous to how some contemporary realists locate or base moral facts in natural facts. Thanks to a referee for JHP for prompting me to clarify this point.

27 As Schopenhauer puts it elsewhere: "In consequence of this egoism, the most fundamental of all our errors is that, with reference to one another, we are not-I. On the other hand, to be just, noble, and benevolent is nothing but to translate my metaphysics into actions ... All genuine virtue proceeds from the immediate and intuitive knowledge [intuitiven Erkenntniss] of the metaphysical identity of all beings" (WWR II 600-01). Schopenhauer does not directly address what sort of error an impartially malevolent being would be involved in, that is, one who equally pursued his own harm and others' harm without distinction (see WWR II 607n.). 
compassionate action, in contrast with egoistic action, arises from a metaphysical insight) is clearly opposed to traditional moral skepticism. ${ }^{28}$ Schopenhauer takes the people who are typically identified as morally good to get fundamental reality right in a profound way. This is a recognizably objective basis for moral conduct, and shows that the importance of moral motivation is indeed more than mere appearance. As with metaethical Platonism, this result comes at the cost of a metaphysical view that might well be regarded as outrageous or fanciful. For these reasons, Schopenhauer's view is part of the family of views that the term 'moral realism' is meant to characterize. This is clear even though we have left open the question of whether Schopenhauer is a cognitivist about moral judgments. That said, one might worry that this impression about Schopenhauer's realism would be undermined if it were combined with a detailed non-cognitivist story. For that reason, I now turn to Schopenhauer's views about moral judgment.

3. Schopenhauer on moral judgment

Schopenhauer does not directly address the question of whether moral sentences or judgments are truth-apt. Moreover, while some passages in $O B M$ are naturally read in a cognitivist way, ${ }^{29}$ others suggest non-cognitivism. There are therefore grounds for worrying

28 There are some significant similarities between Schopenhauer's core view and the ideas involved in the deep ecology movement. See Devall and Sessions, Deep Ecology, Varner, "The Schopenhauer Challenge in Environmental Ethics." On the alternative reading in Shapshay, "Schopenhauer on the Moral Considerability of Animals," Schopenhauer's views align with those of philosophers like Tom Regan.

29 This is true of much of $\S 7$. For instance: "The concepts of wrong and right as synonymous with injury and noninjury, to the latter of which also belongs warding off injury, are apparently independent of all positive legislation and prior to these; thus, there is a pure ethical right, or a natural right, and a pure doctrine of right ... The principles of the same indeed have an empirical origin, insofar as they arise on the occasion of the concept of injury, but in themselves they rest on the pure understanding" (H 4:218/OBM 221, see also H 2:394/WWR I 360-61). 
about the internal consistency of Schopenhauer's views. For those reasons, we may not be able to straightforwardly classify Schopenhauer as a cognitivist or a non-cognitivist. My aim in this section is to show how to read Schopenhauer as a non-cognitivist without undermining the considerations in favor of counting him as a moral realist. That is sufficient for my overall purpose in this paper. I therefore set aside the question of whether there is a comparably plausible cognitivist reading.

The non-cognitivist reading I will describe is based on four more-or-less independent threads in Schopenhauer's discussion: (i) his general views on the limitations of judgment and language, (ii) his criticism of Kant on moral judgments, (iii) his positive view about the role of moral principles as "reservoirs" of compassion, and (iv) his explanations of the concepts of good, bad, and evil.

3.1. The limits of language and judgment

In $O B M$, Schopenhauer alludes to his broadly Kantian understanding of concepts and language, saying:

all peoples, all times, all languages have grasped the concept of reason... as the faculty of universal, abstract, non-intuitive representations, called concepts, which are denoted and fixed through words. It is this faculty alone that actually gives the human being the advantage over the animal. (H 4.148/OBM 160)

Schopenhauer claims that concepts are necessary for judgments (see H 2.77/WWR I 90) and are essential to language: "Language is the first production ... of human reason" (H 2.44/WWR I 60); "language refers ... directly only to thought as such, and thus to abstract concepts, and to 
intuition only be means of these" (H 2.569/WWR I 509); "the learning of a language consists in our linking together a concept and a word for all time" (WWR II 134). The very nature of concepts hinges on the principle of sufficient reason: "the whole essence of concepts, the class of abstract representations, consists of nothing other than the relation the principle of sufficient reason expresses in them" (H 2.48/WWR I 63-64).

The link between concepts and the principle of sufficient reason, however, sets a limit to what can be conceptually (and therefore linguistically) expressed. The principle of sufficient reason "combine[s] representations of whatever sort they may be; but it certainly does not combine representations with the subject, or with something that would be neither subject nor object, but rather merely the ground of the object" (H 2.17/WWR I 36). The principle "has a merely relative and conditional validity within appearances alone" (H 2.38/WWR I 55), where the phenomenal world is the world of distinct individuals in space and time. This allows for concepts and language to represent intuitions (which are not themselves concepts), but only intuitions that fall under the principle of sufficient reason (see, e.g. WWR I $§ 6) .{ }^{30}$

Yet the sort of insight Schopenhauer ascribes to compassion concerns something deeper than the phenomenal world, namely, the world of things in themselves. The latter, he states, is "totally unrepresentable" (H 2.114/WWR I 120). The principle of sufficient reason and the distinctness of individuals break down at world of things in themselves:

the mind of someone evil is enveloped in the veil of māyā... he is caught in the principium individuationis, seeing his own person as utterly distinct and separated from everyone else by a wide gulf... nevertheless, a secret presentiment arises in the innermost part of his consciousness, a presentiment that this order of things is merely appearance, and that, it itself, it is completely different (H 2.431/WWR I 392; see also H 4.267-68/OBM 265). ${ }^{31}$

30 Even in the case of such intuitions, though, Schopenhauer holds that a concept "only ever approximates" intuitive cognition, "as a mosaic approximates a painting" (H 2:70/WWR I 83).

31 Note that the evil person's presentiment (Ahnung), as Schopenhauer describes it here, is purely negative in 
Now, in $O B M$, Schopenhauer does say that the Sanskrit sentence 'tat-twam asi' ('I once more') is the "standing expression" for the insight (H 4.271/OBM 268). But in a letter to Johann August Becker, Schopenhauer states that even this sentence does not literally capture what is at issue. Becker worried that Schopenhauer's explanation is ultimately egoistical (roughly: if the other is me, then motivation by the "other's" pain is motivation by my pain). In response, Schopenhauer writes that, "[you want] to take the phrase 'I once more' ['Ich noch ein Mal'] literally, whereas it is just a figurative turn of expression. For ' $\mathrm{I}$ ' in the proper sense of the term refers exclusively to the individual and not the metaphysical thing in itself which appears in individuals." ${ }^{32}$ So not even the term 'I' can refer to the subject-matter of the insight. This is a radical claim about linguistic limitations. The first-person pronoun carries metaphysical baggage with it that prevents it from properly expressing what a compassionate person grasps. Hence:

a truly good disposition, disinterested virtue, and nobility of mind do not start with abstract cognition, but do nonetheless begin with cognition - namely, an immediate and intuitive cognition that cannot be reasoned for or reasoned away, a cognition that cannot be communicated precisely because it is not abstract. This cognition must come from each person, and this is not truly and adequately expressed in words, but only in deeds, in actions, in the course of a person's life. (H 2.437/WWR I 396-97, my emphasis)

content. He has a presentiment that things in themselves are completely different from how they appear, but not of what that difference might amount to. The compassionate person's insight, by contrast, has positive content. Schopenhauer holds that there is a progression of insight, culminating in the ascetic's renunciation of the world (see Came, "Schopenhauer on the Metaphysics of Art and Morality," 246). So the compassionate person's insight is much better than the evil person's, but one step down from the highest level.

32 Schopenhauer, Gesammelte Briefe, 220-21, translation from Cartwright, Schopenhauer, 510. See also H 2:420/WWR I 382. For worries similar to Becker's, see Scheler, The Nature of Sympathy, 55 and Young, Schopenhauer, 182-83. See Jacquette, The Philosophy of Schopenhauer, 230, Cartwright, "Compassion and Solidarity with Sufferers," 298, and especially Shapshay, "Poetic Intuition and the Bounds of Sense" for relevant discussions. The last clause of the quoted sentence is "... but is directly unknowable" (see also H 4:266/OBM 264). A long-standing worry about Schopenhauer's philosophy is that he seems to both affirm and deny that we can know things in themselves and their relation to appearances, a worry he himself tried to address (WWR II, Ch. 18). See Cartwright, "Two Senses of the Thing-in-Itself in Schopenhauer's Philosophy" for one approach to this issue. Similarly, there is a challenge in seeing how it could make sense to relieve someone's suffering, since suffering is essential to our existence (see Soll, "Schopenhauer on the Inevitability of Unhappiness," 311-12). 
This shows that it is not an accident that Schopenhauer does not use moral language to characterize the metaphysical insight that his core view appeals to. Rather, Schopenhauer appears to be committed to saying that, because of its content, the insight could not be expressed conceptually or linguistically (morally or otherwise). ${ }^{33} \mathrm{He}$ calls the insight "cognition," but this shows that this use of "cognition" ("Erkenntnis") differs from the contemporary use: "[v]irtue does indeed come from cognition, but not from abstract cognition that can be communicated through words" (H 2.434/WWR I 395). Of course, moral judgments or sentences might still play some other role, but they are excluded from the representational state that is at the heart of Schopenhauer's metaethics.

This has an important consequence: on Schopenhauer's view, an egoist cannot make up for her epistemic defect by forming a judgment with the same content as the compassionate person's insight. ${ }^{34}$ Except for a "secret presentiment," the egoist cannot even say or conceive what it is that he is missing. If anything, this strengthens the sense in which Schopenhauer is opposed to traditional moral skepticism.

\subsection{Criticism of Kantian moral judgments}

To see what role Schopenhauer does give to moral judgment, it will be helpful to look in more detail at his criticism of Kant.

33 For similar points, see Goodman, "Schopenhauer and Wittgenstein on Ethics," 438-39.

34 Compare Schopenhauer's description of our grasp of the identity of the will and the body: "this identity ... is itself the most immediate cognition there is; if we do not grasp it as such and keep hold of it we will wait in vain to get it back again somehow in a mediate way, as derived cognition" (H 2:122/WWR I, 127). See also Ch. 18 of $W W R$ II. Also relevant is Schopenhauer's views on music, where he takes music to be epistemically superior to the other arts, including all verbal arts: "music is an unmediated objectivation and copy of the entire will [the thing in itself] ... the other arts speak only of shadows while music speaks of the essence" (H 2:304/WWR I 285). 
Schopenhauer formulates his condemnations of Kantian moral judgments in several ways. As we saw in $\S 2.2$, Schopenhauer sometimes claims that, in attempting to use theological concepts non-theologically, Kant's moral judgments end up being meaningless. For instance: "the concept of ought, the imperative form of ethics, applies only in theological morals, apart from which, however, it loses all sense and meaning [Sinn und Bedeutung verliert]" (H 4.195/OBM 201). Schopenhauer's semantic point is not restricted to the connection with theology, though. He also questions the meaningfulness of legalized moral talk on the grounds that "[t]he actual and original meaning of this term [law] has been restricted to civil law ... a human institution resting on human choice. A second, derivative, figurative, metaphorical meaning has the concept of law in its application to nature" (H 4.120-21/OBM 137). If these are the only meaningful uses of 'ought,' then ought-judgments of the type that Kant gave would be meaningless. If we assume that a meaningless judgment is not truth-apt, then Schopenhauer would be endorsing non-cognitivism for at least a certain range of moral judgments.

On the other hand, Schopenhauer also sometimes condemns Kantian moral judgments as not meaningless, but false. For instance: "I frankly declare my intent to demonstrate that Kant's practical reason and categorical imperative are wholly unjustified, groundless, and fictitious [erdichtet] assumptions" (H 4.116/OBM 133). This sort of formulation makes better sense of some of the details of Schopenhauer's critique, for Schopenhauer claims that several of Kant's central notions are contradictory: "every ought is ... essentially and inevitably hypothetical ... Therefore, an absolute ought is simply a contradictio in adjecto" (H 4.123/OBM 139; similarly see H 4.161/OBM 172 on the contradictoriness of "absolute world" and "ends in themselves"). ${ }^{35}$ He compares such notions to those of "the highest number or the greatest space" (H 4.167/OBM

35 Schopenhauer's criticism of Kant's ethics goes well beyond this. He also thinks Kant makes first-order ethical mistakes, such as Kant's absolutist position against lying (H 4:225/OBM 228). 
177). These passages suggest that Schopenhauer was a cognitivist about a certain range of moral judgments, but took them to be systematically false.

If Schopenhauer's only views about moral judgments were negative ones such as these, then we might have reason to doubt whether his view could be counted as a form of moral realism. ${ }^{36}$ We should consider, then, what Schopenhauer has to offer in terms of positive views.

3.3. The positive role of moral principles

Despite his extended critique of Kant's moral judgments, Schopenhauer is not dismissive of all moral principles. Consider again what he called the "purest and simplest" expression of the "fundamental proposition" of virtue: "Harm no one; rather, help everyone as much as you can" (H 4.137/OBM 150-51). It is surprising that Schopenhauer uses the imperatival form here, given his objections to Kant's use of imperatives. Setting the question of hypocrisy aside, however, it is significant that Schopenhauer gives his fundamental ethical principle a non-truth-apt form. ${ }^{37}$

Following Kant, one might be tempted to reformulate it in truth-apt terms using an 'ought' (e.g. "you ought to harm no one but rather to help everyone as much as you can"), but Schopenhauer is even more emphatic about avoiding the 'ought' [Sollen] than about avoiding the imperatival

\footnotetext{
36 On a related note, Schopenhauer is also suspicious of the role of language in restricting our compassion towards non-human animals, in particular, how we have different words for humans' vs. non-humans' "being pregnant, birthing, dying, and the corpses of animals ... and so through diversity of words to be able to hide the complete identity of the matter" (H 4:239/OBM 240).

37 Perhaps Schopenhauer is implicitly distinguishing two sorts of imperatival forms. When he begins his criticism of Kant, he objects to the "legislative-imperative [legistlatorisch-imperativer] form" (H 4:120/OBM 136). Such legislative imperatives might be distinguished from mere instructions, and Schopenhauer does describe his moral principle as "[a]n instruction [Anweisung] for virtue expressed through a proposition" (H 4:136/OBM 150). In WWR, Schopenhauer declares that "[w]e will not talk about 'oughts' at all: that is how you talk to children, or to nations in their infancy" (H 2:320/WWR I 298). Nonetheless, he grants that there is an aspect of his discussion that "corresponds to and is somewhat analogous with [the 'ought'-using] prescriptive project" (H 2:442/WWR I 401).
} 
form (see $\mathrm{H} 4.123 / O B M$ 139). This may stem from his general view that that "philosophy is always theoretical ... describing without prescribing” (H 2.319/WWR I 297). ${ }^{38}$

We find a possible explanation of why Schopenhauer used the imperatival form later on in $O B M$, when Schopenhauer states what he takes to be the role of abstract moral principles to be:

although principles and abstract cognition generally are in no way the fountainhead or the prime basis of morality, they are nevertheless indispensable for a moral course of life as the container, the reservoir, in which is stored the disposition which has sprung from the source of all morality, which disposition does not flow every moment... Without firmly held principles we should inevitably be vulnerable to anti-moral incentives when they are aroused to affects by external impressions. (H 4.214/OBM 218) ${ }^{39}$

The abstract moral principle to harm no one and to help as much as you can is important, then, not because it correctly describes some aspect of reality, but rather because it serves as the "reservoir" of compassion. The imperatival form of Schopenhauer's fundamental principle would fit this role well, though the role could also be filled by principles with declarative forms such as "[w]hoever brings a child into the world has the duty to support it until it is capable of supporting itself”' (H 4.221/OBM 224) ${ }^{40}$ Such a reservoir-of-disposition view of moral principles could easily be understood in non-cognitivist terms. Since the role of moral judgments, on such a view, is not to describe reality but rather to maintain compassion, it would make sense that such

38 Schopenhauer does not entirely refrain from using "ought" claims, however (e.g. that the world "ought [sollte] not to be" (H 6.323/Parerga and Paralipomena II, 304).

39 These claims partly stem from Schopenhauer's general view about the role of principles. For instance: "the safe preservation of cognition, its communicability as well as its reliable and widespread practical application, all depend on its becoming knowledge proper, or abstract cognition ... intuitive cognition only ever applies to a particular case; it reaches only to what is nearest and no further. So every sustained, complex, systematic activity must start out from and be guided by fundamental principles, that is, abstract knowledge" (H 2:63/WWR I 78). See also H 2:69/WWR I 83.

40 Schopenhauer gives a more sophisticated first-order ethical scheme than what I have said so far suggests. From his fundamental principle, he distinguishes two cardinal virtues: justice and loving-kindness. For more on these, see H 2:226/OBM 213. 
judgments not be truth-apt.

\subsection{The concepts of good, bad, and evil}

The final piece of Schopenhauer's views on moral judgment I will consider is his explanation of the nature of the concepts of good, evil, and badness. In contrast to "many modern philosophers" (H 4.264/OBM 262), Schopenhauer claims that the concepts of good and evil,

are anything but simple, much less given a priori; rather they are expressions [Ausdrücke] of a relation and created by everyday experience. Everything that is consistent with the striving of a particular individual will is called [heisst] good with reference to this will - good food, good roads, a good omen - the opposite is called bad, or concerning living beings, evil. In just the same respect, a person who by virtue of his character, is disinclined to hinder another's striving, but insofar as he can reasonably do so, is favourable and helpful, a person who, thus, does not injure others, but rather, offers help and support when he can, will be called [genannt] by them a good person; hence, the concept of good is applied to him from the same relative, empirical, viewpoint situated in the passive subject. (H 4.265/OBM 263, see also H 2.394-98/WWR I 360-63).

The first thing to note is that Schopenhauer puts his claims here in the passive, with a focus on what people call 'good' or 'bad.' For the reasons discussed in $\S 2.2$, this sort of description of people's usage of terms is consistent with non-cognitivism.

This passage could be read in either a cognitivist or non-cognitivist way. On a cognitivist reading, Schopenhauer would be defining (e.g.) 'good' as that which is consistent with the striving of the speaker's will. Since a (fully) compassionate person would be consistent with the striving of any other individuals' will, judgments about the goodness of persons could be both truth-apt and true. ${ }^{41}$ On a non-cognitivist reading, the term 'good' would be expressing relations

41 For a development of a cognitivist reading on the basis of this passage and related ones, see Varner, "The Schopenhauer Challenge in Environmental Ethics," 216-19. By contrast, David Cartwright suggests that Schopenhauer takes moral judgments to proceed from a point of view that is based in "the affective responses of the 
to one's own will, but not describing it. Either reading would be consistent with Schopenhauer's core metaethical view.

3.5 Putting the pieces together

I have argued that there are various non-cognitivist suggestions in Schopenhauer. It is not obvious how to put these pieces together, not least because they are not obviously consistent with each other. I will conclude this section by outlining one unified non-cognitivist reading, but I do not claim it is the only possible one. The form of non-cognitivism I describe here is, to the best of my knowledge, unlike any in contemporary metaethics. ${ }^{42}$

The central motivation for Schopenhauer's non-cognitivism, on this reading, is the fact that the metaphysical insight involved in compassion concerns something that is beyond the reach of concepts and language. The majority of people "in all times and lands" use moral judgments as a mental reservoir for storing up compassionate motivation for times when they lose that insight. This is facilitated by the fact that they use terms like 'good' to express (but not describe) certain motivational states. ${ }^{43}$ Unfortunately, these moral judgments were also

actor and an impartial and uninvolved witness" (Cartwright, "Schopenhauer on the Value of Compassion," 254, see H4.204/OBM 209). On Cartwright's proposal, an action with genuine moral worth is one that elicits feelings of approval from the actor and the impartial witness. Cartwright's proposal is consistent with cognitivism (e.g. the view that "has moral worth" means "would be approved by actor and impartial witness"), but could also be seen as a noncognitivist interpretive framework.

42 Michael Slote also suggests that moral judgments might be "a kind of reservoir of moral(ly good) motivation" drawn from empathy (Slote, Moral Sentimentalism, 87). Slote, however, is a cognitivist, and does not give any epistemically or metaphysically deep status or grounding to empathy/compassion.

43 Michael Allen Fox suggested a somewhat similar reading, though he does not directly confront the issue of cognitivism. He claims that Schopenhauer "naturalizes" ethics: "Ethics is naturalized, then, in that convergent observations and lines of investigation point toward compassion, a component of our psychological make-up and the key moral emotion, as the source of behaviour that is universally understood to be ethically commendable. Moral principles are merely reminders to redirect our attention to this source" (Fox, "Boundless Compassion," 376). See also Jacquette, The Philosophy of Schopenhauer, 225ff. 
connected to theological notions by Europeans. Because that connection involved a conceptual confusion that interfered with judgments' ability to serve as motivational reservoirs, these judgments became detached from their original purpose and so meaningless.

On this reading, Schopenhauer would join anti-realist non-cognitivists in denying that statements like 'we ought not harm others' or 'we should help others' were true. However, unlike anti-realists, he would hold that someone who, because of compassion, accepted and lived by imperatives like 'do not harm others' and 'help others' was thereby epistemically superior to someone who accepted and lived by imperatives like 'harm others' and 'do not help others.' The former sort of person's motivations would be reservoirs of deep metaphysical insight, whereas the latter person's would be reservoirs of metaphysical illusion. ${ }^{44}$

A qualification: the non-cognitivist elements I described in Schopenhauer's views primarily concern the states of actual humans who are engaged in action. Even setting aside the more cognitivist-sounding passages mentioned above, it is consistent with all I have said that there could be some way of adapting moral concepts in a cognitivist way, e.g. taking 'morally good' to just mean 'would be desired by an epistemically ideal agent.' This might be modeled on the way that Schopenhauer develops the concept of the will, a concept of something that is also beyond the reach of reason and normal language (see H 2.132-33/WWR I 135-37). ${ }^{45}$ Such adapted moral concepts might then be used to form true judgments. If so, then the result might be a sort of cognitivist realism. Yet such an adaption of our moral concepts, by Schopenhauer's lights, would be a change for the worse, both morally and epistemically. For then moral

44 Alternatively, one might say that "we should help others" is partly true, whereas "we should harm others" is entirely false. Perhaps this might be a case where the only way to express the relevant truth is to "subtract" the false legal connotations from such statements (for an approach to partial truth along these lines, see Yablo, Aboutness).

45 Along these lines, after concluding that talk of a "highest good" is incoherent, Schopenhauer grants that we could retain the expression "out of habit, giving it honorary or emeritus status." This would involve a merely a figurative use, however (H 2:427-28/WWR I 389). 
judgments would lose their intimate link to metaphysical insight.

The non-cognitivist reading I have described would make sense of much of what Schopenhauer wrote, though it is a further question whether it could make sense of all the cognitivist-sounding passages. Most importantly, for my purposes, this non-cognitivist reading would not yield any obvious threat to his claims to have presented a non-skeptical grounding to morality. The next section elaborates on this point.

4. The consistency of non-cognitivism with Schopenhauer's core view

Above, I claimed that non-cognitivism is consistent with Schopenhauer's core metaethical view and that it would not undermine his view's status as a form of moral realism. In this final section, I will say a bit more in support of this claim, first by discussing the intuitions it relies on (and their limitations) and second by describing two other possible forms of noncognitivist realism.

4.1. The intuitive case for moral realism and its limitations

My argument for Schopenhauer's being a moral realist has attempted to appeal to our sense of whether that view has certain defining features: being relevantly similar to Plato's, showing that the importance of morality is more than "mere appearance," standing in contrast to moral skepticism and conventionalism, implying that morally bad people (but not good people) 
are necessarily missing out on some aspect of reality, and providing some sense according to which morality is "objective." 46 I hold that, on reflection, we can see that Schopenhauer's view has all these features, but like any appeal to intuitions, this argument is not irresistible.

Other defining features for moral realism might of course be proposed, of course, and it would have to be decided on a piecemeal basis whether Schopenhauer's view satisfied them. ${ }^{47}$ My argument would of course be stronger if it appealed to a precise sufficiency condition for moral realism. I am not aware of any sufficiency condition that would be less controversial than the definition of moral realism I have been challenging, however.

In light of these limitations of my argument, someone could simply insist that no noncognitivist could be counted as a moral realist. If so, then I think we would need to develop a more refined metaethical taxonomy. For if Schopenhauer is a moral anti-realist, he is one that gives morality a much more robust metaphysical and epistemological basis than any traditional anti-realist does. Our metaethical terminology should capture the profound difference between

46 Here is a more specific case for taking Schopenhauer's project to be of a kind with Plato's. In Book II of the Republic, Glaucon asks Socrates to defend justice by showing that it is a "sort of good we love for its own sake, and also for the sake of its consequences-knowing, for example, and seeing, and being healthy" (Plato, Republic 344c, my emphases). Arguably, Socrates' response is to show that just people have a sort of health that no unjust people have. Schopenhauer's view would be taking another alternative from Glaucon's list: showing that just people have a sort of sight that no unjust people have.

47 One potential defining feature, connected to cognitivism and assumed by many contemporary realists, would be having moral terms refer to robustly real entities or (what is arguably the same thing) having moral entities be robustly real. Whether or not Schopenhauer was a cognitivist about moral judgments, his view would probably not have this feature. For Schopenhauer, moral terms could at most refer to individuals and their relationships - hence his claim that "the moral significance of an action can lie only in its relations to others" (H 4:206/OBM 211). Yet, as an idealist, Schopenhauer does not think that individuals or their relationships are robustly real (for a relevant discussion, see McDermid, "Schopenhauer and Transcendental Idealism", 78-79). Insofar as the argument of the main text shows that this feature comes apart from the others, then that argument might show that there are reasons for rejecting this feature along with cognitivism as being part of moral realism. After all, this feature by itself is not sufficient for a plausible form of moral realism; consider the view that "morally-good" refers to a robustly real physical particle. Moreover, some moral realists have argued that it is a mistake to require metaphysical entities corresponding to normative claims (e.g. Nagel, The View from Nowhere, 139; Scanlon, Being Realistic about Reasons, 62). Along those lines, Schopenhauer regards his philosophy as moving to a "higher, metaphysical-ethical [metaphysisch-ethischen] standpoint" (H 5.333/Parerga and Paralipomena I 273) beyond our ordinary view of the world. One could understand this higher standpoint in terms of something like ethical insights whose contents are more "real" or "true" than any individual or relation in the empirical world (or judgments concerning those individuals and relations). 
metaethical views like Schopenhauer's and views like Hume's, even if both views are noncognitivist.

4.2. Other forms of non-cognitivist realism?

My discussion of Schopenhauer in this paper was partly in the service of a more general point: that non-cognitivism is consistent with moral realism. For the sake of that general point, I will briefly consider two other possible forms of non-cognitivist moral realism. To my knowledge, neither has been explicitly defended in the literature. A full defense of these views would be non-trivial, for both views require some ambitious philosophical claims. These claims are different from Schopenhauer's more contentious metaphysical claims, though. Seeing this, I hope, will help show that the combination of non-cognitivism and moral realism is more than a one-off theoretical possibility.

One possible form of non-cognitivist realism could be reached if we accepted a proposal by the phenomenologist Max Scheler (though Scheler himself was probably a cognitivist, and was critical Schopenhauer ${ }^{48}$ ). In his discussion of compassion, Scheler claims that compassion "frees us ... from an illusion; an illusion which is always to be found embodied in the naïve view of the world" (Scheler, The Nature of Sympathy, 58). The illusion in question is "the egocentric ascription to others of an ontological status of mere dependence on oneself" (Scheler, The

\footnotetext{
48 Scheler held that there are values, but that compassion was "blind to value" (Scheler, The Nature of Sympathy, 5). In his view, the value of other people was recognized through love (Scheler, The Nature of Sympathy, 113). Scheler read Schopenhauer as claiming that compassion itself has moral value, which he sees as absurdly entailing that one should cause suffering so as to have more opportunities for compassion (Scheler, The Nature of Sympathy, 53). For reasons given above, I think Scheler misread Schopenhauer.
} 
Nature of Sympathy, 59), that is, metaphysical solipsism. ${ }^{49}$ Like Schopenhauer, then, Scheler takes compassion to free us from a metaphysical illusion that is somehow contained in egoism. If we combined this view with the first core claim from Schopenhauer's core view (that we attribute moral worth to acts based on compassion), then the result would be a view with much of the structure of Schopenhauer's, but with a more modest metaphysics. ${ }^{50}$

The second possible form of non-cognitivist realism is further removed from Schopenhauer's view. Consider a combination of a traditional theological metaethics and noncognitivism. For example, say that God has commanded humans to be benevolent and truthful, and that God gives eternal reward to people who follow these commandments and eternal punishment to those who do not. Say also that while we finite beings can describe these theological facts at an indeterminate level in non-moral terms, our moral concepts are our attempt to give a determinate characterization of how things relate to God's will. If a determinate characterization of God's will is impossible for us, these concepts might end up being meaningless and make our moral judgments not truth-apt. Nonetheless, these meaningless judgments would still be gesturing towards the same sort of metaphysical facts involved in traditional divine command theory, perhaps in something like the way that Schopenhauer thought that 'tat-twam asi' gestured at the way subjects are in themselves. A judgment like 'thou shalt not kill' would be, strictly speaking, neither true nor false, but it might still be the best we can do at gesturing towards God's will, and a much better gesture than 'thou shalt kill.'

I am not claiming that either of these views is plausible. I am claiming, however, that

\footnotetext{
49 There are places where Schopenhauer's characterization of the egoistic illusion include something like this. For example: "He for whom all others were always Not-I, indeed, who fundamentally took only his own person to be truly real ... sees in death all reality and the entire world perishing with his self" (H 4:273/OBM 270).

$50 \mathrm{My}$ own view is that the best way to develop a metaphysically modest Schopenhauerian view would be to appeal to a Lockean epistemology about ideas resembling qualities in their objects, since compassionate pain resembles other types of pain. For more, see Marshall, "Lockean Empathy."
} 
despite their non-cognitivism, both views would have a strong claim to be included in the family of views that, in contrast to moral skepticism, attempt to give an objective place to morality, show that its importance is not mere appearance, etc. If that is right, then contemporary metaethics has been wrong in taking cognitivism to be a necessary condition for moral realism.

\section{Conclusion}

My primary aim in this paper was to show that Schopenhauer's views pose a challenge to the dominant, cognitivism-based understanding of moral realism. Along the way, I provided a non-cognitivist interpretation of Schopenhauer's views on moral judgment, an interpretation that I claimed was consistent with his anti-skeptical attempt to find a basis for morals. For the challenge, it is enough for if Schopenhauer's non-cognitivist view is even a borderline case of moral realism, though I have claimed that it is more than that. It is also enough for the challenge if a non-cognitivist reading of Schopenhauer is consistent with his core metaethical view, regardless of whether some cognitivist reading might be more plausible overall.

In the introduction, I noted that if this challenge holds up, it would imply that contemporary metaethics has focused too narrowly on moral judgment. I will conclude by spelling out this implication a bit. Nothing in my discussion has shown that there is anything wrong with realist views that aim to earn their claim to realism by showing that moral judgments are both truth-apt and true. Nor has anything in my discussion suggested that there is anything wrong with using non-cognitivism as part of an anti-realist view. However, my discussion is meant to suggest that an acceptance of non-cognitivism by itself does not settle the question of 
whether a view is realist or anti-realist. One must also look at what the view takes to be going on metaphysically and epistemologically in the agents, actions, and states of affairs that moral judgments are directed towards. If the view gives the right sort of metaphysical or epistemological privilege to those agents, actions, or states of affairs to which we typically attribute positive moral value, then, I hold, it should be counted as part of the family of moral realist views. This of course raises the question of what makes some metaphysical or epistemological status of "the right sort." That question, however, must be left for another occasion. $^{51}$

51 For comments and discussion, thanks to Melissa Merritt, Tristram Oliver-Skuse, Mike Raven, Jeff Sebo, Jonathan Simon, and Bill Talbott. 
Bibliography and Abbreviations

Atwell, John. Schopenhauer: The Human Character. Philadelphia: Temple University Press, 1990.

Blackburn, Simon. Essays in Quasi-Realism. New York: Oxford University Press, 1993.

_ _ "Moral Realism.” In Morality and Moral Reasoning, edited by John Casey, 101-24. London: Methuen, 1971.

Came, Daniel. "Schopenhauer on the Metaphysics of Art and Morality." In Vandenabelle, $A$ Companion to Schopenhauer, 237-48 .

Cartwright, David. "Compassion and Solidarity with Sufferers: The Metaphysics of Mitleid." European Journal of Philosophy 16 (2008): 292-310.

—, Schopenhauer: A Biography. Cambridge: Cambridge University Press, 2010.

— , "Schopenhauer on the Value of Compassion." In Vandenabelle, A Companion to Schopenhauer, 249-65.

— , "Two Senses of the Thing-in-Itself in Schopenhauer's Philosophy." Idealistic Studies 31 (2001): 31-53.

Copp, David. "Realist-Expressivism and Conventional Implicature.” In Oxford Studies in MetaEthics, Volume 4, edited by Russ Shafer-Landau, 167-202. Oxford: Oxford University Press, 2008.

Devall, Bill and Sessions, George. Deep Ecology: Living as if Nature Mattered." Layton, Utah: Gibbs Smith, 1985.

Drier, James. "Meta-Ethics and the Problem of Creeping Minimalism.” Philosophical Perspectives 18 (2004): 23-44. 
Foot, Philippa. "Moral Realism and Moral Dilemma." Journal of Philosophy 80 (1983): 379-98.

Fox, Michael Allen. "Boundless Compassion.” The European Legacy 11 (2006): 369-87.

Gibbard, Allan. Thinking How to Live. Cambridge, Mass.: Harvard University Press, 2003.

Goodman, Russell B. "Schopenhauer and Wittgenstein on Ethics." Journal of the History of Philosophy 17 (1979): 437-47.

Guyer, Paul. "Schopenhauer, Kant, and Compassion.” Kantian Review 17 (2012): 403-29.

Jacquette, Dale. The Philosophy of Schopenhauer. London: Acumen, 2005.

Janaway, Christopher. "Schopenhauer's Philosophy of Value," in Neill and Janaway, Better Consciousness: Schopenhauer's Philosophy of Value, 1-10.

Joyce, Richard. "Moral Anti-Realism." In The Stanford Encyclopedia of Philosophy (Summer 2009 Edition), edited by Edward N. Zalta. URL = $<$ http://plato.stanford.edu/archives/sum2009/entries/moral-anti-realism/>.

Hume, David. Treatise on Human Understanding. Edited by David Fate Norton and Mary J. Norton. Oxford: Oxford University Press, 2000. [Treatise]

Kant, Immanuel. Lectures on Logic. Edited and translated by J. Michael Young. Cambridge: Cambridge University Press, 1992.

Korsgaard, Christine. The Constitution of Agency. Oxford: Oxford University Press, 2008.

—, The Sources of Normativity. Cambridge: Cambridge University Press, 1996.

Lessing, Gotthold Ephaim. Gesammelte Werke. Edited by Paul Rilla. Berlin: Aufbau-Verlag, 1968.

Lillehammer, Hallvard. "Review of Russ Shafer-Landau, Moral Realism: A Defense." Notre Dame Philosophical Reviews (2004). URL =

$<$ https://ndpr.nd.edu/news/23768-moral-realism-a-defense/> 
Magee, Bryan. The Philosophy of Schopenhauer. Oxford: Clarendon, 1983.

Marshall, Colin. “Lockean Empathy.” Southern Journal of Philosophy (forthcoming).

McDermid, Douglas. "Schopenhauer and Transcendental Idealism.” In Vandenabelle, $A$ Companion to Schopenhauer, 70-86.

Nagel, Thomas. The View from Nowhere. Oxford: Oxford University Press, 1986.

Neill, Alex and Christopher Janaway, eds. Better Consciousness: Schopenhauer's Philosophy of Value. Wiley-Blackwell, 2005. [Better Consciousness]

Oddie, Graham. Value, Reality, and Desire. Oxford: Oxford University Press, 2005.

Plato. Republic. Translated by C.D.C. Reeve. Indianapolis: Hackett, 2004.

Railton, Peter. “Moral Realism.” Philosophical Review 95 (1986), 163-207.

Sayre-McCord, Geoffrey. "Introduction: The Many Moral Realisms.” In Essays on Moral Realism, edited by Geoffrey Sayre-McCord. Ithaca: Cornell University Press, 1988.

Scanlon, Timothy. Being Realistic about Reasons. Oxford: Oxford University Press, 2014.

Scheler, Max. The Nature of Sympathy. Translated by Peter Heath. New Brunswick: Transaction Publishers, 2008.

Schopenhauer, Arthur. Gesammelte Briefe. Edited by Arthur Huebscher. Bonn: Bouvier Verlag Herbert Grundmann, 1986.

- On the Basis of Morals. In Schopenhauer, Two Fundamental Problems of Ethics, 121272. $[O B M]$

- On the Freedom of the Will. In Schopenhauer, Two Fundamental Problems of Ethics, 33-120. $[O F W]$

- , On Will in Nature. In Schopenhauer, On the Fourfold Root of the Principle of Sufficient Reason and Other Writings. Edited and translated by David Cartwright, Edward Erdman, 
and Christopher Janaway, 303-448. Cambridge: Cambridge University Press, 2010. $[O W N]$

—, Parerga and Paralipomena, Volume 1. Edited and translated by Sabine Roehr and Christopher Janaway. Cambridge: Cambridge University Press, 2014.

—, Parerga and Paralipomena, Volume 2. Translated by E. F. J. Payne. Oxford: Clarendon Press, 1974.

—, Sämtliche Werke, 7 volumes. Edited by Arthur Hübscher, $4^{\text {th }}$ ed. Manheim: F. A. Brockhaus, 1988. [H]

—, The World as Will and Representation, Volume I. Edited by Christopher Janaway. Translated by Judith Norman and Alistair Welchman. Cambridge: Cambridge University Press, 2010. [WWR I]

— York: Dover, 1958. [WWR II]

- Two Fundamental Problems of Ethics. Edited and translated by David Cartwright and Edward Erdman. Oxford: Oxford University Press, 2010.

Shafer-Landau, Russ. Moral Realism: A Defense. Oxford: Oxford University Press, 2003. Shapshay, Sandra. "Poetic Intuition and the Bounds of Sense: Metaphor and Metonymy in Schopenhauer's Philosophy." European Journal of Philosophy 16 (2008): 211-29. —_, "Schopenhauer on the Moral Considerability of Animals." Presented at 2014 NYU Conference on Issues in Modern Philosophy (Manuscript).

Sears, David. Compassion in the Jewish Tradition. Northvale, NJ: Jason Aronson, 1998.

Slote, Michael. Moral Sentimentalism. Oxford: Oxford University Press, 2010.

Soll, Ivan. "Schopenhauer on the Inevitability of Unhappiness." In Vandenabelle, A Companion 
to Schopenhauer, 300-14.

Street, Sharon. "Reply to Copp: Naturalism, Normativity, and Varieties of Realism Worth Worrying About.” Philosophical Issues 18 (2008): 207-28.

Vandenabelle, Bart, ed. A Companion to Schopenhauer. Oxford: Wiley-Blackwell, 2012.

Varner, G.E. "The Schopenhauer Challenge in Environmental Ethics." Environmental Ethics 7 (1985): 209-29.

Yablo, Stephen. Aboutness. Princeton: Princeton University Press, 2014.

Young, Julian. Schopenhauer. London: Routledge, 2005. 